\title{
History of the official publication of the Japanese Society of Gastroenterology: from Gastroenterologia Japonica to Journal of Gastroenterology
}

\author{
Tsuneyoshi Yao
}

Published online: 8 January 2015

(C) Springer Japan 2015

Firstly, congratulations on the 50th anniversary in 2015 of the official publication of the Japanese Society of Gastroenterology (JSGE). I have had a long and close association with this publication. For 26 years, between 1975 and 2001, I served in a number of editorial positions, including Associate Editor, Editor-in-Chief, and Editorial Director. I was Editor-in-Chief in 1994 when we changed the name of the journal [1], and I suspect that is why I have been asked to write this piece.

\section{The Gastroenterologia Japonica years (1966-1993)}

Gastroenterologia Japonica started as a quarterly journal. In volumes $1-7$, there were 4-12 original papers per year and up to seven case reports per year, but the content of most issues was dominated by proceedings.

At around the time of volume 10 in 1974, there was a significant increase in the number of submissions. There was so much material that Gastroenterologia Japonica became a bimonthly journal, starting with volume 13 in 1977. Still, the rate of submissions kept rising. Some 50-76 original papers (four to six per issue) were being published each year, as well as ten case reports in 5 years. And yet the pages of Gastroenterologia Japonica were still dominated by proceedings.

T. Yao $(\bowtie)$

Fukuoka University, Zokumyoin 1-1-1, Chikushino

Fukuoka 818-8502, Japan

e-mail: yao12_25@yahoo.co.jp

T. Yao

Sada Hospital, Watanabe-Dori 2-4-28, Chuo,

Fukuoka 810-0004, Japan
At that time, there were 13 editors $^{1}$ on staff, including some who were also working on Nippon Shokakibyo-gakkai Zasshi. Every paper submitted had to be reviewed by two editors, which meant that each editor was reading up to three English-language papers and five to seven Japaneselanguage papers per month. And this was back in the days when we did not have computers or cell phones. The papers would be sorted at the editorial office, then distributed to a roster of editors devised by the Editor-in-Chief. There was no editorial board as such, and the editors had to work very hard indeed.

\section{From Gastroenterologia Japonica to Journal of Gastroenterology}

The end-of-year review by the Editorial Committee in 1992 raised the following key issues:

1. Impact factor close to zero.

2. More original papers needed to boost the impact factor.

3. Current title Gastroenterologia Japonica seen as too local, putting off potential contributors

4. Title should be changed to Journal of Gastroenterology.

5. Add Review and Editorial sections to boost appeal to readers.

Following numerous meetings and extensive discussions, a team led by Editorial Director Hisaaki Shimazu

\footnotetext{
11993 Editorial Committee: Tsuneyoshi Yao (Editor-in-Chief), Tsutomu Chiba (Associate Editor), Michio Imawari, Hiromasa Ishii, Shinnichi Kakumu, Isao Makino, Seiki Matsuno, Kazuhiko Okabe, Kiwamu Okita, Mitsugi Sugiyama, Masao Tanaka, Akira Terano, Hidenobu Watanabe and Tsuyosi Yabana.
} 
(Kagoshima), Akira Terano (Tochigi), and the Secretariat began negotiating with a number of publishers. It was resolved that:

1. The proposed title, Journal of Gastroenterology, had not been registered anywhere in the world.

2. The editing and publication processes should be outsourced to reduce the financial burden on the JSGE.

To this end, editing and publication were contracted out to Springer-Verlag Tokyo in a format that remains largely intact to this day.

Gastroenterologia Japonica was formally wound up with volume 28, and the Journal of Gastroenterology started from volume 29 .

\section{The new era of the Journal of Gastroenterology}

The new official publication of the JSGE was issued as a bimonthly journal from January 1994, and became a monthly journal in 2000 .

After the journal had been rebadged as the Journal of Gastroenterology, there was a spike in the number of submissions over the ensuing decade, from 205 in 1994 to 365 in 2003. The number of submissions from outside Japan increased from zero to 83 over the same period. Accordingly, the success ratio of papers chosen for publication fell from 60 to $37 \%$. The number of reviews rose from two or three per year to 10-14 per year, the number of editorials rose from two or three to 28-30, and the number of case reports rose from two or three to around 30 . The number of original papers, meanwhile, remained fairly constant through the decade at around 85-90 per year.

Since 1995, the Editorial Board has included eight international members who do not serve as editors of the Japanese-language journal. The impact factor of the journal improved from 0.477 in 1995 to 1.179 in 2003, and continues to rise. This improvement can be attributed to the energy and enthusiasm of the editors-in-chief, Hiromasa Ishi (1996-1997), Akira Terano (1998), Kiwamu Okita (1999), and Tsutomu Chiba (2000), as well as the tireless efforts of the hardworking editors and the Secretariat.

I am confident that the journal has a very promising future presenting more outstanding papers that will be cited for the next 10 years, or even the next 50 years, while at the same time attracting an expanded readership and a higher reputation, and hence resulting in greater scientific impact of this most worthy publication.

\section{Reference}

1. Yao T. Casting off the image of a "local" journal to embrace a more international audience: the new Journal of Gastroenterology. J Gastroenterol. 1994;29:1. 